\title{
Orange Peel as Novel Substrate for Enhanced Invertase Production by A. niger in Solid State Fermentation
}

\author{
S.B. Mashetty ${ }^{1}$ and Vijaykumar Biradar $^{2}$ \\ ${ }^{1}$ Department of Chemistry, Karnatak College Bidar, India \\ ${ }^{2} P G$ Studies and Research Centre in Biotechnology, Karnatak College Bidar, India \\ *Corresponding author:
}

\section{A B S T R A C T}

\section{Keywords}

Orange peel, Invertase, Solid state fermentation and Aspergillus niger.

Article Info

Accepted:

10 March 2019

Available Online:

10 April 2019
Effective invertase enzyme production was achieved with orange peel as carbon source compared to all other tested also residues. Among different nitrogen sources, yeast extract supported maximum enzyme production. Various fermentation parameters $(\mathrm{pH}$ of the medium, incubation temperature, time, volume in addition to carbon and nitrogen sources) also influenced the rate of invertase production. Maximum enzyme production of 55 units was observed in the medium of $\mathrm{pH} 4$ containing $2 \%$ of orange peel having particle size of $3-1.5 \mathrm{~mm}$ containing $1 \%$ of sucrose and $1 \%$ yeast extract in 96 hours of incubation.

\section{Introduction}

Invertase

[ $\beta$-fructofuranosidases

(EC.3.2.1.26)] is an enzyme that catalyses the hydrolysis of sucrose (table sugar). The resulting mixture of fructose and glucose is called inverted sugar syrup. Invertase, cleave the $\mathrm{O}-\mathrm{C}$ (fructose) bond. It is namely used in the food and beverage industry to produce candies, chocolates, lactic acid and glycerol, etc (Aehlew, 2004). Among micro organisms Saccharomyces cerevisae commonly called bakers yeast in the primary strain used for the production of invertase commercially. The common microorganism used for the study is Asperigillus niger and Candida utilis (Icrwin et al., 2001 and Schuster et al., 2002).

The objective of present study is to utilize the agro-industrial residue which is primarily composed of complex polysaccharides that strengthens microbial growth for the production of industrial important enzymes. The solid state fermentation process of enzyme production have potential advantages i.e. simplicity in operation high productivity, less favourable for contamination (Singhania et al., 2009). 


\section{Materials and Methods}

The microorganism Aspergillus niger was isolated from the soil of sugarcane field of Bidar, (India) by serial dilution method. The cultures of these were obtained from the plate inoculated with diluted sample of $10^{-8}$. The fungal strain is propagated on potatodextrose agar medium (PDA) at $30^{\circ} \mathrm{C}$ and maintained at $4^{\circ} \mathrm{C}$.

\section{Fermentation conditions / culture medium}

The medium used for the production of enzyme under solid state fermentation has constituents $(\mathrm{gm} / \mathrm{l})$ of $25 \mathrm{gm}$ sucrose, $10 \mathrm{gm}$ yeast extract, $1 \mathrm{gm}$ ammonium sulphate $\left[\left(\mathrm{NH}_{4}\right)_{2} \mathrm{SO}_{4}\right], \quad 0.1 \mathrm{gm}$ calcium chloride $\left(\mathrm{CaCl}_{2} \cdot 2 \mathrm{H}_{2} \mathrm{O}\right)$, and Potassium dihydrogen phosphate $\left(\mathrm{KH}_{2} \mathrm{PO}_{4}\right)$. The $\mathrm{pH}$ of the medium adjusted to 5 .

\section{Processing of the substrate}

The fruit peel waste (orange, pomegranate, sapota peel and pineapple) were collected from the market and juice centre washed, sliced and shade dried and grinded stored in polythene bag at room temperature. They were autoclaved at $15 \mathrm{lbs}$ for 20 minutes before use (Uma et al., 2010).

\section{SSF: Solid- state fermentation}

The powdered substrate $40 \mathrm{gm}$ (orange / pomegranate/sapota/ pineapple) was taken in $250 \mathrm{ml}$ Erkenmeyer flask and moistened with culture medium/ solid state medium in the ratio of $2: 1(\mathrm{w} / \mathrm{v})$. The substrate is mixed thoroughly and autoclaved for 20 minutes at $121^{\circ} \mathrm{C} 15 \mathrm{lbs}$ and cooled to room temperature. The sterlised medium was inoculated with $10^{6}$ spores/ml inoculums. After thorough mixing the contents flasks were incubated in a incubator at $35^{\circ} \mathrm{C}$ for $36 \mathrm{hrs}$ intervals. All the sets were prepared in duplicate. At the end of fermentation $50 \mathrm{ml}$ of distilled water was added to the fermentation substrate and kept on rotatory shaker at $10000 \mathrm{rpm}$ for 30 minutes and the supernatant used as crude enzyme for assay.

\section{Enzyme assay}

The estimation of reducing sugar was done by dinitrosalicylic acid (DNS) method. $0.1 \mathrm{ml}$ enzyme solution was incubated with $0.9 \mathrm{ml}$ sucrose in $0.03 \mathrm{M}$ in acetic buffer (pH 5). To stop the reaction $1 \mathrm{ml}$ of dinitrosalicylic acid (DNS) reagent was added and heated for 3 minutes in a boiling water bath. The solution was cooled to room temperature. Finally the absorbance was read at $540 \mathrm{~nm}$ using spectrophotometer (Miller, 1959). One unit of invertase (1U) is defined as the amount of enzyme which liberates one mole of glucose/minute/ml under the assay conditions.

The optimization of the medium on the production of invertase was done by studying the effects of various factors like Inoculum size: $4 \mathrm{ml}$ inoculum size, Incubation time: 96 hours, Carbon sources: sucrose $1 \%$, Nitrogen sources: Yeast extract 1\%, $\mathrm{pH}: 5$ and Temperature: $30^{\circ} \mathrm{C}$ (4 days old culture of $4 \mathrm{ml}$ inoculum size was taken for the study of parameters).

\section{Optimization study}

The optimization of parameters like incubation time, incubation temperature, inoculums size, initial $\mathrm{pH}$ and the nutritional sources like different substrates, addition of carbon sources, nitrogen sources are known to influence the enzyme production. These parameters were optimized by the conventional methods of optimizing one independent parameter at a time while fixing other values (Miller 1959). The parameter optimized in one experiment was maintained in subsequent experiments (Shafiq et al., 2003 and 2004). 


\section{Results and Discussion}

\section{Effect of incubation period}

To estimate the optimum incubation period for invertase enzyme production, fermentation flasks were incubated for different time duration from 1 to 6 days. After every 24 hours, the exhausts were evaluated for invertase activity. Maximal filters value of enzyme production were reached between 72 and 96 hours. Further increase in incubation period resulted in a decrease in invertase production (Fig. 1; Tables 1 and 2). This might be due to reduction in the availability of nutrients in the medium and accumulation of toxic products of metabolism (Shafiq et al., 2003).

\section{Effect of incubation temperature}

Temperature plays an important role for the production of the invertase by $A$. niger. The effect of temperature on invertase production was studied by incubating the culture media (production media) at various temperatures such as $25,30,35,40^{\circ} \mathrm{C}$. The strain has shown maximum enzyme production at a temperature of $30^{\circ} \mathrm{C}$ (Fig. 2 and Table 3) and the same results were observed by Shafiq $e t$ al., 2004. Hence it was found favorable for $A$. niger however, the enzyme activity was not significant because of denaturation of active sites of enzyme at higher temperatures.

\section{Effect of inoculum volume}

Different volume of inoculums such as 1, 2, 3, 4 and $5 \mathrm{ml}$ were tested for their ability to induce invertase production in the production medium. The maximum invertase activity was observed at the $4 \mathrm{ml}(45 \mathrm{IU} / \mathrm{ml})$ of inoculum level. The inoculum size was further increases the production of enzyme gradually decreased due to the fact that at high level of inoculum size. Fungi grow fast by consuming the essential nutrients at the initial stages and rapid accumulation of byproducts into the fermentation medium observed reference 4.the reason the low production of enzyme at the inoculum size below than optimal was due to the slow growth of the organism and extended time period to utilize nutrients properly (Schuster et al., 2002).

\section{Effect of pH}

The effect of optimum $\mathrm{pH}$ for invertase production by $A$. niger was determined by adjusting the $\mathrm{pH}$ values of $3,4,5,6,7$ and then inoculated with $4 \mathrm{ml}$ inoculum prepared from 4 days old culture and incubated at $30^{\circ} \mathrm{C}$ for 4 days.

The strain has shown maximum invertase production at the medium $\mathrm{pH} 5$ (Fig. 3 and Table 2) the results of others (Vitolo et al., 1995) are evidenced with this result. This shows that enzyme is not stable towards alkaline conditions so the sucrose inversion efficiency is also affected indirectly (Balasunbaram and Pandit, 2001).

\section{Effect of carbon sources}

Different carbon sources such as glucose, fructose, lactose, sucorse and raffinose at $1 \%$ concentration were added to the medium for the invertase production. The $\mathrm{pH}$ of the medium was adjusted to 5 and $4 \mathrm{ml}$ inoculums of 4 day old culture at $30^{\circ} \mathrm{C}$ for 4 days.

Among all the carbon sources tested sucrose gave the best result Vitolo and Yassuda 1991 and Rubio and Navarro 2006). These results were also supported by the findings of Cairns et al.,, (1995), who reported that invertase production in some other fungi were induced by sucrose, glucose and fructose are not involved in the induction synthesis of invertase in A. niger (Rubio and Navarro 2006). 


\section{Effect of nitrogen sources}

The effect of different nitrogen sources were tested by adding $1 \%$ different nitrogen sources like peptone, urea, yeast extract to the production medium ( $\mathrm{pH}$ 5) containing sucrose as the carbon sucrose with $4 \mathrm{ml}$ culture inoculum of 4 days old culture (Kamble and Borate 2012). The flasks were incubated at $30^{\circ} \mathrm{C}$ for 96 hours.

Table.1 Effect of carbon source on invertase production by A. niger

\begin{tabular}{|c|c|}
\hline Conditions of carbon sources & Enzyme activity (IU/ML) \\
\hline Fructose & 44 \\
\hline Glucose & 38 \\
\hline Lactose & 26 \\
\hline sucrose & 50 \\
\hline maltose & 25 \\
\hline
\end{tabular}

Table.2 Effect of nitrogen source on invertase

\begin{tabular}{|l|c|}
\hline Conditions of nitrogen sources & Enzyme activity (IU/ML) \\
\hline Peptone & 42 \\
\hline Urea & 35 \\
\hline Yeast extract & 52 \\
\hline Malt & 40 \\
\hline Casein & 40 \\
\hline
\end{tabular}

Table.3 Optimized conditions for invertase production by A. niger

\begin{tabular}{|l|l|}
\hline Optimized parameter & Optimized conditions \\
\hline Incubation time & 96 hours \\
\hline Incubation temperature & $30^{\circ} \mathrm{C}$ \\
\hline Inoculums volume & $4 \mathrm{ml}$ \\
\hline Initial pH & 5 \\
\hline Carbon source & Sucrose \\
\hline Nitrogen source & Yeast extract \\
\hline
\end{tabular}

Fig.1 Effect of incubation time on invertase production using A.niger

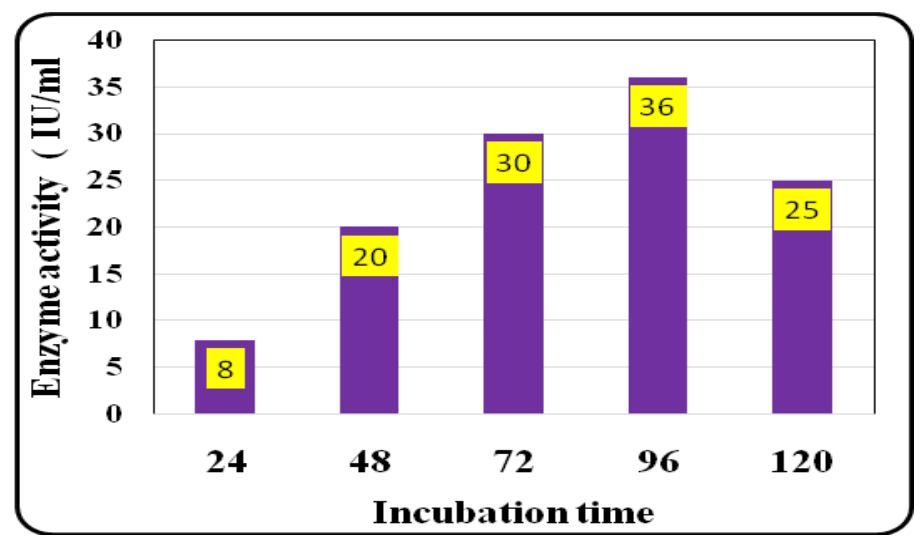


Fig.2 Effect of incubation temperature on invertase production using A.niger

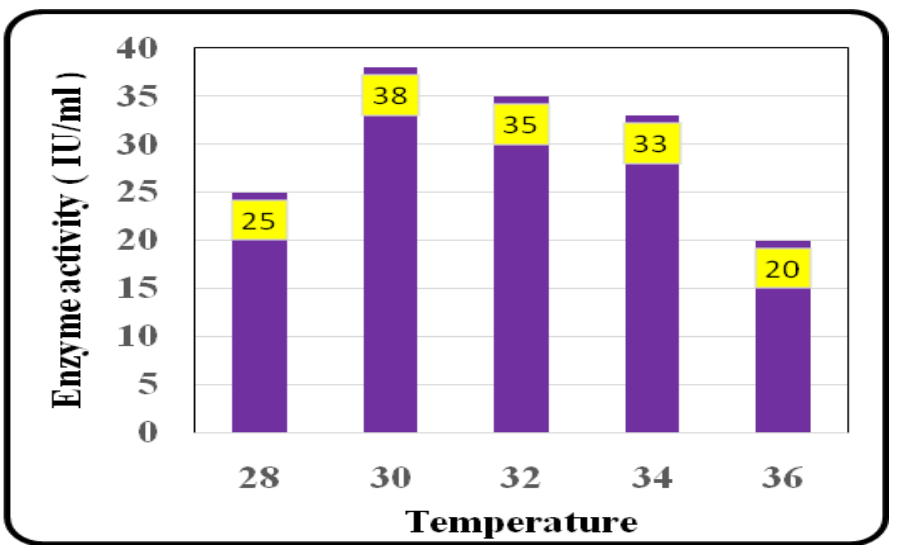

Fig.3 Effect of inoculum volume on the invertase production using A. niger

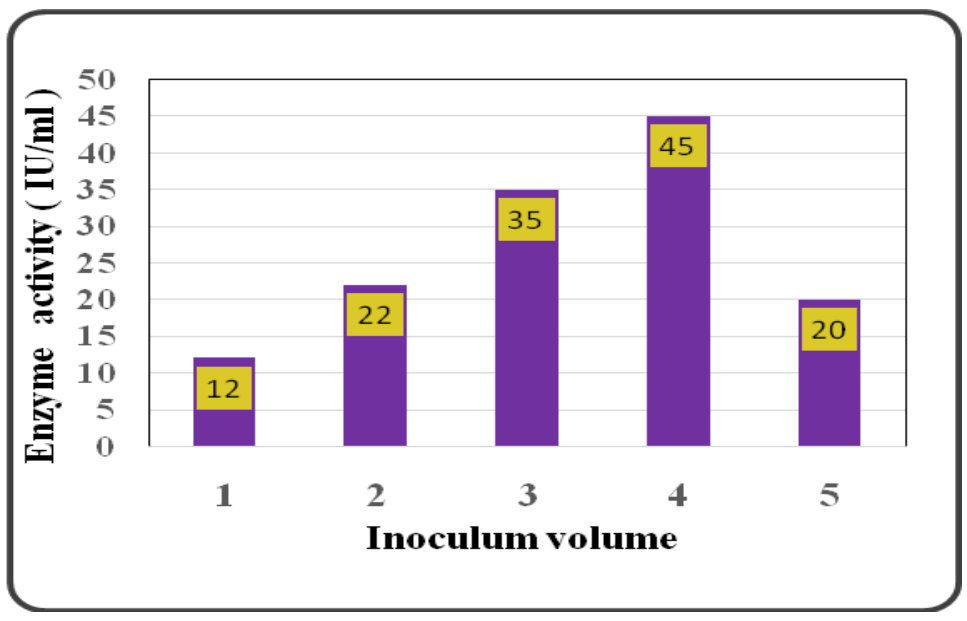

Fig.4 Effect of $\mathrm{pH}$ on the invertase production using A. niger.

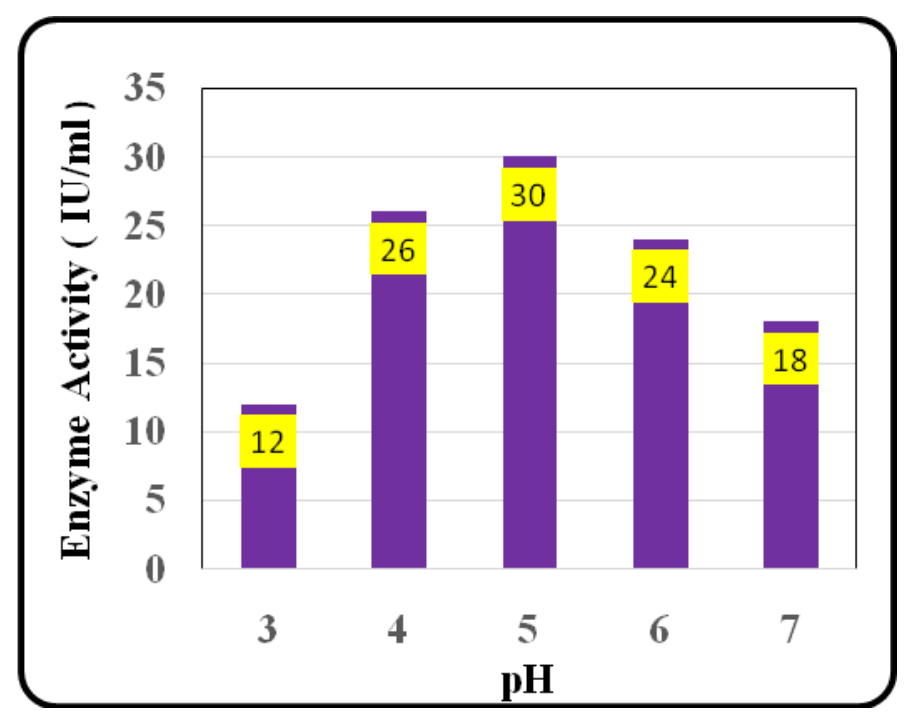


Fig.5 Effect of carbon sources on the invertase production using A. niger

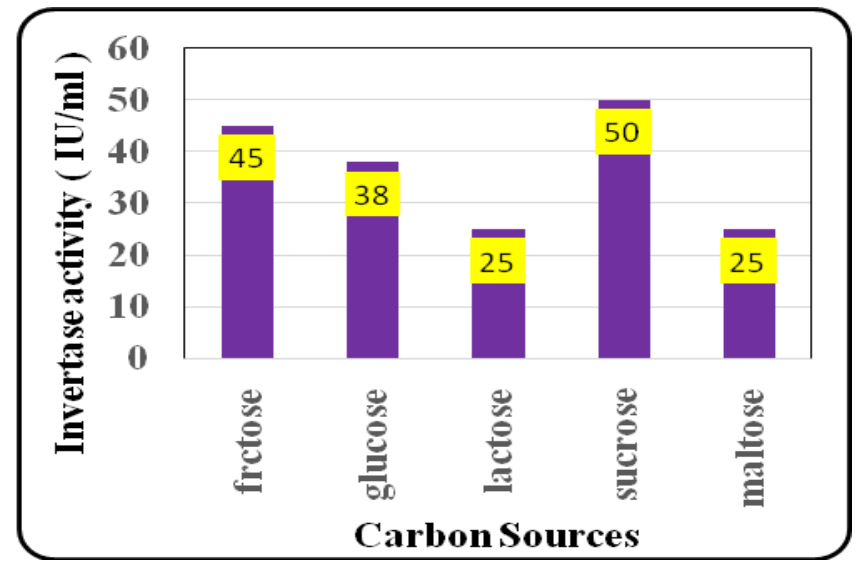

Fig.6 Effect of nitrogen sources on the invertase production using A. niger

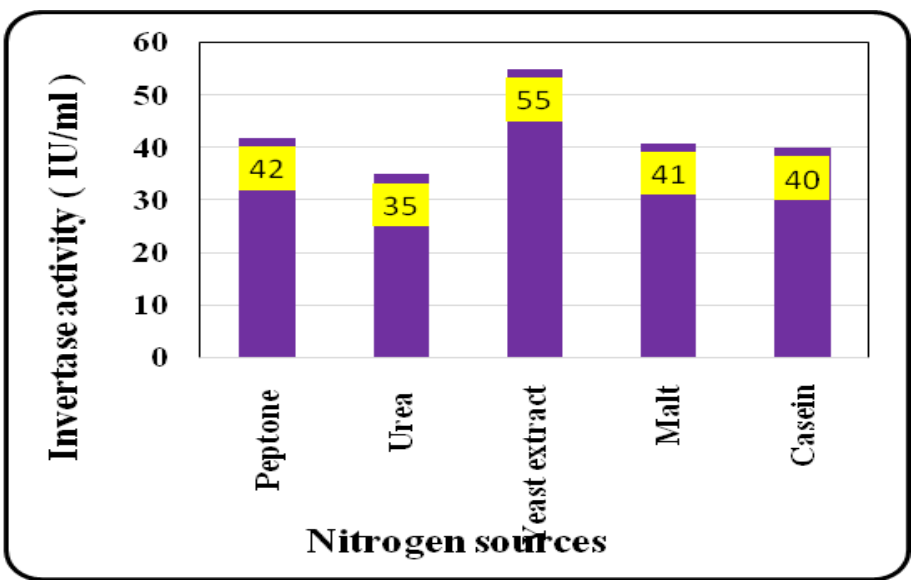

Fig.7 Effect of various substrates on the invertase production using A. niger

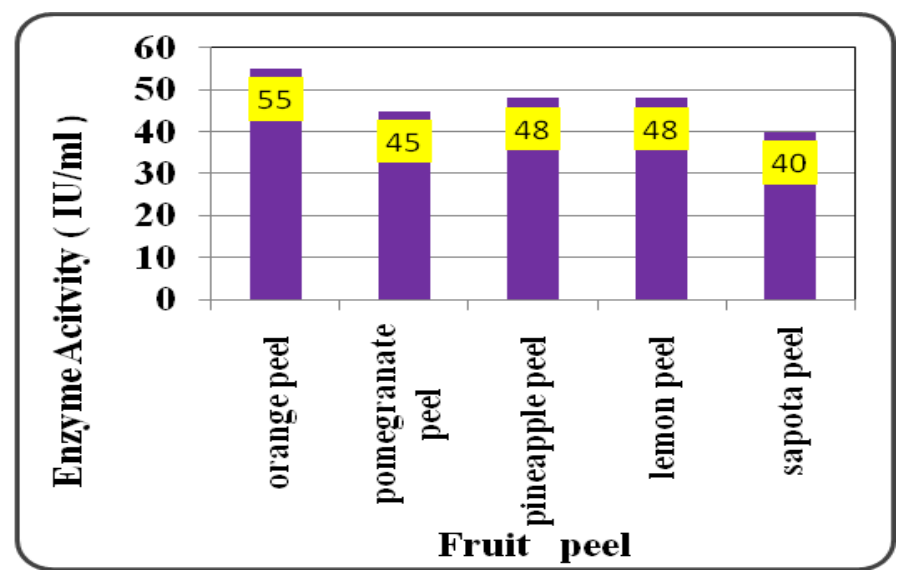

The maximum invertase production was shown using yeast extract as nitrogen source (Fig. 4 and Table 2). Similar results that yeast extract was the best nitrogen source for invertase from a cladosporium cladosprioides in SmF (Uma et al., 2012). Wherer as some reported that the peptone + yeast extract was significant in invertse production by 
Saccharomyces cerevisie (Kamble and Borate 2012) (Fig. 5-7).

\section{Effect of substrates on enzyme activity}

Different agricultural byproducts such as orange peel pomegranate peel sapota peel, pineapple peel and lemon peel were tested for production of invertase enzyme. The maximum invertase production was recorded using orange peel $(55 \mathrm{IU} / \mathrm{ml})$ supplemented medium.in our investigation 5 agricultural residues such as peels of orange, Pomegranate, Pineapple, Lemon and Sapota have been used as substrate maximum invertse production (IU/ML) WAS Recorded with orange peel similar results as orange peel as the best substrate for the maximum production of invertse was observed using Saccharomyses cervisivae (Pandey et al., 2001, Alegre et al., 2009, and Shankar et al., 2013) and also using A. niger (Asha et al., 2016). Some investigated as the best agro residue as carbon source using $A$. niger Vijaykumar et al., 2016).

In conclusion, the investigation suggests that the orange peel could be an alternative and promising substrate for the production of invertase by $A$. niger.

The solid state fermentation (SSF) is considered as most eco-friendly process. In addition, this work will act as first time information to researchers who want to explore the possibilities of converting waste to wealth and value addition. Since orange peel utilized within process are readily accessible agricultural (horticultural) waste with little or no cost and also contain an appreciable amount of invertase. These agricultural wastes are regarded as low cost substrate using $A$. niger. This work will not only lead to the reduction in the production cost of invertase but also help to decrease the pollution load resulting from these agricultural wastes

\section{Acknowledgement}

The author would like to thank to UGC for sanctioning Minor Research Project entitled Enzyme production using agricultural waste in solid state Fermentation. A study wide diary No 2572- MRP/ 15-16/ KAGUO13/UGC SWRO dated 31 March 2016. The author also express gratitude to coworkers and the principal of the college, for their support and encouragement throughout duration of the project work.

\section{References}

Aehlew 2004. Industrial enzymes. Enzymes in food applications, enzymes in industry. Production and applications. Wiley.

Alegre, A.C.P., M. D. L. T. D. M. Polizeli, H. F.T. J. A. Jorge, Guimaraes 2009. Production of thermostable invertase by Aspergillus caespitosus under submerged or solid state fermentation using agro industrial residues as carbon source. Brazilian Journal of Microbiology, 40: 612-622.

Asha, L., Raju, C.H. King, P. and Arvind, J. 2016. Production of invertse by Aspergillus niger under solid state fermentation using orange peel as substrate. Adv. Crop Sci Tech., 4: 6.

Balasunbaram, B. and Pandit, A. B. 2001. Significance of location of enzymes on their release during microbial cells destruction. Biotech Bioeng, 75: 607-614.

Cairns, A. J., Howarth, C. J. and Pollock, C. J. 1995. Characterization of acid invertase from the snow mould Monographella nivalis: A mesophillic enzyme from a psychrophilic fungus. J. New Physiologist, 130: 391-400.

Icrwin, C.C., Doerries, I. Marism and Von Stocker, U. 2001. Quantitative analysis of the regulation scheme of invertase expression in Saccharomyces cerevisiae. Biotechnol Bioeng, 75: 247-258. 
Kamble, P. and Borate, J. C. 2012. Effect of nitrogen sources on the production of invertase by yeast Saccharomyces cerevisiae 3090. International Journal of applied biology and pharmaceutical technology. 3: 297-300.

Klich, M. A. 2002. Identification of common Aspergillus species. Centralburean Voor Schimmel cultures.

Miller, G. L. 1959. Use of dinitrosalicylic reagent for determination of reducing sugars. Analytical chem., 31: 426-428.

Pandey, A., Csoccol, J. Rodriguez-leon, P. and Nigam. 2001. In: Solid state fermentation in biotechnology-fundamentals and applications, Asiatech Publ. Inc., New Delhi. 50-225.

Rubio, M. C. and Navarro, A. K. 2006. Regulation of invertase synthesis in $A$. niger. J- Enzyme and microbial. Tech. 39: 601-606.

Schuster, E., Dunn, N. Frisvad, J. Van Dijck, P. 2002. on the safety of Aspergillus niger- a review. Applied microbiology and Biotechnology 59: 426-435.

Shafiq K., S. Ali and Ul-Haq, I. 2003. Time course study for yeast invertase production by submerged fermentation. J. Bacterial., 3: 984-988.

Shafiq, K., Ali and Ul-Haq, I. 2004. Temperature optima for invertase secretion by yeast in synthesis medium Pak. J. life Soc., 2(1): 21-23.

Shankar, T., Thangamathi, P. Rama, R. Sivakumar, T. 2013. Optimization of invertse production using Saccharomyces cerevisiae under varying cultural conditions. International Journal Of
Biochemistry and Biophysics, 1(3): 4756.

Singhania, R R., Patel, A.K. Soccol, C. R. and Pandey 2009. Recent advances in solid state fermentation, Biochem Eng J., 44: 13-18.

Ul.-Haq, I. and Ali, S. 2005. Invertase production from a hyper producing Saccharomyces cerevisiae strain isolated from dates, Pak. J. Bot, 37(3): 749-759.

Uma, C., Gomathi, D. Muthulakshmi, C. and Gopalkrishna 2010. Production purification and characterization of invertase by Asperigillus flavus using fruit peel waste as substrate. Adavances in Biological Research, 4: 31- 36.

Uma, C., Gomathi, D. Ravikumar, G. Kalaiselvi, M. Palaniswamy, M. 2012. Production and properties of invertase from a Cladosporium cladosporioides in $\mathrm{SmF}$ using pomegranate peel waste as substrate. Asian Pacific Journal of Tropical Biomedicine, 5605-5611.

Vijaykumar, B., Mashetty, S.B. Patil, M.S. Pooja, L. and Pooja, S. 2016. Screening of agroresidues and factors influencing for the production of B- fructofuranosidase from Aspergillus niger, Int. J. Appl. Res., 2(9): 180-85.

Vitolo, M. and Yassuda, M. T. 1991. Effect of sucrose concentration on the invertase activity of intact yeast cells. Biotechnol Lett. 13: 53-56.

Vitolo, M., Duranti, M. A. Pellegrim, M. B. 1995. Effect of $\mathrm{pH}$ aeration and sucrose feeding on the invertase activity of intact $S$. cerevisiae calls grown in sugarcane black strap molasses. J. Industrial microbiology, 15(2): 12-24.

\section{How to cite this article:}

Mashetty, S.B. and Vijaykumar Biradar. 2019. Orange Peel as Novel Substrate for Enhanced Invertase Production by A. niger in Solid State Fermentation. Int.J.Curr.Microbiol.App.Sci. 8(04): 1114-1121. doi: https://doi.org/10.20546/ijcmas.2019.804.128 